\title{
Religious discourse, cyberspace and social media: A trajectory from Muslim millennial's perspective
}

\author{
T. Thoriquttyas* \& N. Muyassaroh \\ Universitas Negeri Malang, Malang, Indonesia \\ N. Ahsin \& A. Naim \\ IAIN Kediri, Kediri, Indonesia
}

\begin{abstract}
The various interpretations of the Quranic verses on social media is still a contextual topic to be discussed. In fact, Muslim millennial groups often rely on social media as a way of learning Islam (i.e. Twitter, Facebook, Instagram etc). The purpose of this study is to snapshoot the trajectory of religious discourse in cyberspace from a Muslim millennial perspective. In this study, the Muslim millennial group was represented by the freshmen of Universitas Negeri Malang (UM). Data was collected through interviews and in-depth observation of 145 students who studied Islamic education's course from Faculty of Letters, Faculty of Sports Science and Faculty of Social Sciences. The results obtained show that there is a relationship between respondents' responses on religious discourse and social media. The various responses are indicating that Muslim have varied views relating to the intersection of religious discourse and social media
\end{abstract}

Keywords: cyberspace, social media, religious discourse

\section{INTRODUCTION}

Social media has the potential to become a primary source for accessing religious knowledge and disseminating moderatism as well as radicalism to the Muslim millennial generation. Again, discussions about the relationship between the internet and religion have great significance. Discussing moderatism and radicalism in religious views from cyberspace is a complicated topic (Baulch \& Pramiyanti2018; Hussain \& Silcock 2019). It needs a multidisciplinary approach to uncover the dynamic of religious discourse in cyberspace. In the Indonesian context, the prevalence of religious discourse on social media is wide-spread, more so for Indonesian Muslims (Faiqah \& Pransiska 2018).

As predicted by Hootsuite (We are Social) in 2017, the users of social media in Indonesia reached 160 million users in January of 2020. The number of social media users in Indonesia increased by 12 million (8.1 percent) between April of 2019 and January of 2020 (Slama 2017). Social media use in Indonesia was at 59 percent in January of 2020 (Herdiansah \& Husin 2018; Slama 2018). In the Indonesian context, there are the five popular social media platforms in 2020: YouTube (88\%), WhatsApp (84\%), Facebook (82\%), Instagram (79\%) and Twitter (56\%). With this number of users, the Muslim millennial generation becomes the majority group who is involved in social media.

This project portrays the social media use of Indonesian Muslims on the discourse of moderatism and radicalism. This warranted an approach to research that enabled young people to discuss their views and experiences, explain why they engage in moderatism or radicalism and give their motivations for doing so.

\footnotetext{
*Corresponding author: titisthoriq.fs@um.ac.id
} 
Ahmad Syafii Maarif stated that radicalism cannot be defined as terrorism (Suhaimi \& Raudhonah 2020). According to him, radicalism is more concerned with the way religious person acts and the accumulation of model attitudes daily (Arifianto 2019; Irham et al. 2020). On the other hand, the term of terrorism includes criminal acts and has political objectives. In addition, the phenomenon of radicalism is more related to religious cases and terrorism requires global action. Radicalism can sometimes transform into terrorism when the circumstances allow (Woodward 2010).

The formulation of radicalism always adjusts its linearity to the trajectory of the times (Azra 2005; Nur 2020). Several years ago, acts of radicalism in the name of religion often used physical force as a tool (Nur 2020). However, this is currently changing. The current portrait of radicalism is often narrated in social media using virtual instruments. The virtual instrument can be interpreted as the model of distributing and disseminating religious content through social media.

It is interesting to note that there are new modifications in the spread of radicalism. One of them is the emergence of radical Islamic books in the market. These books have unique characteristics especially when it comes to the type of publisher. The book's publisher has ideological closeness to the author or the book's themes, so that according to Azra, there is a close relationship between the publisher and the book's themes that have radical content (Azra 2005; Fealy 2012; Salem 2016). This da'wah method is used specifically for conservative Islamic groups. According to the Salem, the kind of publications from conservative Islamic circles can be easily found and accessed by the public, such as magazines, pamphlets, VCDs and any content uploaded on their website (Salem 2016).

Winarni in her research shows that the radicalism that is currently developing attracts religion, especially Islam in situations and conditions that are inevitable and as if it creates connections between the interpretation of Islam and violence (Winarni et al. 2017; Winarni et al. 2019). This is certainly detrimental to Islam and all its components, because it portrays Islam as tough, stiff and "angry" (Winarni 2014). The thing that must be remembered and pondered deeply is that the birth of Islam in its long historical trajectory was never colored with blood and decorated with sharp swords, but Islam was brought by the Prophet Muhammad with messages of peace.

This study examines social media as it currently takes a very large portion and role in providing good information that is directed at radicalism and moderatism, especially with segmentation for the millennial generation. Both moderatism and radicalism also use social media lines to disseminate their thoughts. This is emphasized by the enthusiasm of the millennial generation, especially when it comes to digital literacy. Propaganda and the recruitment of militant members via social media is a sad part of progress.

\section{METHODS}

This study used a case study method by observing the experiences of the Muslim millennial generation on social media and other internet resources related to the context of Islamic discourse practices on social media. In addition, the data consisted of descriptions obtained through online and offline interviews with purposively determined informants, comprising of Islamic information services through internet platforms, websites and social media.

We therefore used focus group discussions (FGD) and individual interviews in this research. In addition to our work with young Muslims, we interviewed respondents who played a significant role. Our intention in these interviews was to explore their views about their engagement in social media. In this study, the Muslim millennial generation was represented by the students who had an academic background through Indonesian Higher Education. A number of participants were involved in Islamic religious education from the Faculty of Letters, the Faculty of Sports Science and the Faculty of Social Sciences at Universitas Negeri Malang (145 students).

As stated in Table 1, the respondents were male ( 60 respondents) and female ( 85 respondents). From three kinds of faculties, female students dominated the research sample. The mapping of respondents was expected to broaden the scope of research and perform it more comprehensively. 
Table 1. Number of the respondents.

\begin{tabular}{lll}
\hline Faculty & Male & Female \\
\hline Faculty of Letters & 10 & 35 \\
Faculty of Social Sciences & 10 & 33 \\
Faculty of Sport Sciences & 40 & 17 \\
Total & 60 & 85 \\
\hline
\end{tabular}

This research is focused on how religious discourses on social media are colored and circulated on establishing the perception on Muslim millennials. This study was conducted throughout 20192020. The social media platforms chosen as the focus of this study were Twitter, Instagram and Facebook. Three kinds of social media platforms were chosen because of their highly constant activity in distributing Islamic discourses from the Muslim millennial generation. The data will be elaborated on, in detail, to illustrate the practices of Islamic learning on the Internet in relation to moderatism and radicalism.

\section{RESULTS AND DISCUSSION}

Based on research in the field using the interview method, it was found that $78 \%$ of respondents admitted that they had accessed content that led to a radical understanding of Islam found on social media. Meanwhile, $22 \%$ of respondents claimed to have never accessed radical content. From the $78 \%$ of respondents who accessed radical content, almost $46 \%$ of these students accessed radical content "accidentally." The accident is because respondents often search for keywords to help them in their daily problems and after surfing social media, find themselves "stuck" on websites that contain radical content. Their ignorance led to acceptance of this knowledge and according to the respondents, they found it difficult to filter out this radical knowledge. After accessing the radical content, respondents revealed that the final solution when experiencing "confusion" in responding to the content was to confirm and check the truth of the information with the Islamic Religious Education lecturer in their class. As stated by Monica, one of the students in the English Department, Faculty of Letters, stated:

"I often use Google to get information about Islamic studies, things that are still confusing, ranging from the law of usury, bombing, jihad and the relationship between Islam and science. The content often leads to portraits of Islam which are "rigid", "cruel" and "sadistic" ... after receiving many explanations like that, I usually meet the Islamic Religious Education Lecturer (PAI) to get confirmation of this."

Therefore, according to the researcher's analysis, one of the functions of Islamic Religious Education (IRE) Lecturers in Public Universities is as a validator of Islamic understandings as experienced directly by students, especially on social media. Lecturers of IRE play a strategic position in efforts to deradicalize the understanding of Indonesian Higher Education's students, moreover, the penetration of social media as a new platform for da'wah further strengthens the challenge of radicalism for the millennial generation. This finding strengthens the idea that educators had a significant influence in controlling moderatism and radicalism in a learning context (Alama 2020).

Furthermore, the mapping of social media's use of respondents is dominated by three platforms: Twitter, Facebook and Instagram.

Table 2 indicates that the respondents have ways of interacting with social media, such as Twitter, Facebook and Instagram. Furthermore, the faculties of Letters, Social Sciences and Sport Sciences have the highest numbers for embracing social media. Facebook had the most users (129 users), followed by Twitter (99 users) and Instagram (104 users).

Related to the previous research on national surveys for religious attitudes in schools and universities in Indonesia conducted by the Center for Islamic and Community Studies (PPIM) UIN 
Table 2. The mapping of social media from the respondents.

\begin{tabular}{llll}
\hline Faculty & \multicolumn{2}{l}{ Social Media } \\
\cline { 2 - 4 } & Twitter & Facebook & Instagram \\
\hline Faculty of Letters & 38 & 45 & 39 \\
Faculty of Social Sciences & 29 & 43 & 35 \\
Faculty of Sport Sciences & 32 & 41 & 30 \\
\hline
\end{tabular}

Jakarta in 2018 stated that students that do not have internet access have a more moderate opinion compared to those with access to the internet. This fact is quite alarming as $51.1 \%$ of student Muslims show a tendency towards intolerance towards minorities. Furthermore, 58.5 percent of student respondents have religious views on radical opinions (Faiqah \& Pransiska 2018).

The various responses to student's perceptions on facing the content of moderatism and radicalism are examined below:

Table 3. The mapping of student responses facing moderatism and radicalism.

\begin{tabular}{|c|c|c|c|}
\hline \multirow[t]{2}{*}{ Faculty } & \multicolumn{3}{|l|}{ Social Media } \\
\hline & $\begin{array}{l}\text { Confirming with } \\
\text { the Lecturer }\end{array}$ & $\begin{array}{l}\text { Browsing } \\
\text { Social Media }\end{array}$ & $\begin{array}{l}\text { Asking other } \\
\text { students }\end{array}$ \\
\hline Faculty of Letters & 19 & 20 & 6 \\
\hline Faculty of Social Sciences & 10 & 18 & 15 \\
\hline Faculty of Sport Sciences & 12 & 27 & 18 \\
\hline
\end{tabular}

Table 3 indicated that respondents have various responses facing moderatism and radicalism in social media. There are three kinds responses: first, confirming with the lecturer (41), second, browsing on social media (75) and thirdly, discussing with other students (39). The use of virtual networks, such as social media as instruments of radicalization and moderation recruitment, will arouse sympathy from individuals who feel the need for solidarity in brotherhood, poverty, social imbalances and political frustration. Browsing social media as an alternative way to learn about Islam needs to be a focus for educators because educators have the responsibility to confirm any questions from students relating to religious issues which are ideally characterized by religious moderation.

This study strengthens previous research (Hilmy 2013; Salem 2016; Arif 2020), that lecturers have the responsibility to assist students in gaining access to information related to Islamic studies with mainstream religious moderation. From the data above, there are quite a lot of students who intentionally or unintentionally access learning content that is indicated to be radical and fundamental, so the role of lecturers must be increased so that students are able to filter this out. The challenge going forward is the need to increase insight and competence, as well as sensitivity for lecturers, so that information relating to religious moderation can become the initial foundation in research and policy development in the relevant government sectors.

In addition, the use of social media as a vehicle for the spread of religious moderation and the ability to use it are important things that must be mastered by lecturers (Herdiansah \& Husin 2018; Slama 2018). Lecturers are expected to be able to operate social media and implement them into the framework of mainstreaming religious moderation. This condition is in accordance with the characteristics of the millennial generation who are close to social media, technology and information. 


\section{CONCLUSION}

Discussing the social media and cyberspace and how it influences the Muslim millennial generation is a complicated discourse which involves multiple disciplines. The relationship between social media — as well as technology in general — and religion is essentially reciprocal and interconnected. Online reciprocal relationships are basically intended to describe the connections between the context of Islamic learning practices on the internet and the spectrum of moderatism and radicalism. Under this assumption, social media has become a part of Muslims' daily lives. Islamic knowledge on the internet, as presented in this article, has been demonstrated to have a reciprocal relationship. Optimizing the use of social media as a medium to spread moderatism and to prevent radicalism by targeting the millennial Muslim generation. The development of internet applications, especially on social media, influences the patterns of recruitment and disseminations of radicalism. They are like a multipurpose tool that can be used to teach individuals and groups.

\section{REFERENCES}

Alama, M. 2020. A Collaborative Action in the Implementation of Moderate Islamic Education to Counter Radicalism, International Journal of Innovation, Creativity, and Change, 11(7), pp. 497-516.

Arif, M. K. (2020). Moderasi Islam (Wasathiyah Islam) Perspektif Al-Qur'an, As-Sunnah Serta Pandangan Para Ulama Dan Fuqaha. Al-Risalah, 11(1), pp. 22-43.

Arifianto, A. R. 2019. Islamic campus preaching organizations in Indonesia: Promoters of moderation or radicalism? Asian Security, 15(3), pp. 323-342.

Azra, A. 2005. Islam in Southeast Asia: Tolerance and Radicalism. Centre for the Study of Contemporary Islam, Faculty of Law.

Baulch, E. and Pramiyanti, A. 2018. Hijabers on Instagram: Using visual social media to construct the ideal Muslim woman. Social Media + Society, 4(4), p. 2056305118800308.

Faiqah, N. and Pransiska, T. 2018. Radikalisme Islam Vs Moderasi Islam: Upaya Membangun Wajah Islam Indonesia Yang Damai. Al-Fikra: Jurnal Ilmiah Keislaman, 17(1), pp. 33-60.

Fealy, G. 2012. Islamisation and politics in Southeast Asia: The contrasting cases of Malaysia and Indonesia in Islam in world politics. Routledge, pp. 159-176.

Herdiansah, A. G. and Husin, L. H. 2018. Religious Identity Politics on Social Media in Indonesia: A Discursive Analysis on Islamic Civil Societies. Jurnal Studi Pemerintahan, 9(2), pp. 187-222.

Hilmy, M. 2013. Whither Indonesia's Islamic Moderatism? A reexamination on the moderate vision of Muhammadiyah and NU. Journal of Indonesian Islam, 7(1), pp. 24-48.

Hussain, S. A. and Silcock, B. W. 2019. Social Media Campaign to Improve Religious Tolerance. Narratives of Storytelling across Cultures: The Complexities of Intercultural Communication, p. 217.

Irham, I., Haq, S. Z. and Basith, Y. 2020. Deradicalising religious education: Teacher, curriculum and multiculturalism. Epistemé: Jurnal Pengembangan Ilmu Keislaman, 15(1), pp. 39-54.

Nur, I. 2020. Embracing Radicalism and Extremism in Indonesia with the Beauty of Islam. Asian Research Journal of Arts \& Social Sciences, pp. 1-18.

Salem, Z. 2016. The Religion of Social Media: When Islam Meets the Web.

Slama, M. 2017. Social media and Islamic practice: Indonesian ways of being digitally pious. Digital Indonesia: connectivity and divergence. Singapore: ISEAS Publishing, pp. 146-162.

Slama, M. 2018. Practising Islam through social media in Indonesia. Taylor \& Francis.

Suhaimi, S. and Raudhonah, R. 2020. Moderate Islam in Indonesia: Activities of Islamic Da'wah Ahmad Syafii Maarif. Ilmu Dakwah: Academic Journal for Homiletic Studies, 14(1), pp. 107-128.

Winarni, L. 2014. The Political Identity of Ulama in the 2014 Indonesian Presidential Election. Al-Jami'ah: Journal of Islamic Studies, 52(2), pp. 257-269.

Winarni, L., Agussalim, D. and Bagir, Z. A. 2019. Memoir of Hate Spin in 2017 Jakarta's Gubernatorial Election; A Political Challenge of Identity against Democracy in Indonesia. Religió: Jurnal Studi Agamaagama, 9(2), pp. 1-23.

Winarni, L., Yudiningrum, F. R. and Wijaya, S. H. B. 2017. Social Media and the Issue of' Gafatar'in Indonesia. KnE Social Sciences, pp. 115-119.

Woodward, M. 2010. Muslim education, celebrating Islam and having fun as counter-radicalization strategies in Indonesia. Perspectives on Terrorism, 4(4), pp. 28-50. 